\title{
Purification and Characterization of an $\alpha$-Galactosidase from Aspergillus fumigatus
}

\author{
Sebastião Tavares de Rezende $^{1^{*}}$, Valéria Monteze Guimarães ${ }^{1}$, Marília de Castro \\ Rodrigues ${ }^{2}$ and Carlos Roberto Felix ${ }^{2}$ \\ ${ }^{1}$ Departamento de Bioquímica e Biologia Molecular; Universidade Federal de Viçosa; 36.571-000; \\ srezende@ufv.br; Viçosa - MG - Brazil; ${ }^{2}$ Departamento de Biologia Celular; Universidade de Brasília; 70.910-900; \\ Brasília - DF - Brazil
}

\begin{abstract}
Aspergillus fumigatus secreted invertase ( $\beta$-fructofuranosidase) and $\alpha$-galactosidase enzymatic activities able to hydrolyzing raffinose oligosaccharides (RO). $\alpha$-Galactosidase was induced by galactose, melibiose and raffinose, but galactose was the most efficient inducer. It was purified by gel filtration and two ion exchange chromatographies and showed Mw of $54.7 \mathrm{kDa}$. The purified enzyme showed maximal activity against pnitrophenyl- $\alpha$-D-galactopyranoside (pNPGal) at $\mathrm{pH} 4.5-5.5$ and $55{ }^{\circ} \mathrm{C}$, and retained about $80 \%$ of the original activity after incubation for 90 minutes at $50^{\circ} \mathrm{C}$. The $K_{M}$ for pNPGal was $0.3 \mathrm{mM}$. Melibiose was hydrolyzed by the enzyme but raffinose was very poor substrate.
\end{abstract}

Key words: Aspergillus fumigatus, $\alpha$-galactosidase, raffinose oligosaccharides

\section{INTRODUCTION}

The $\quad \alpha$-galactosidases $\quad(\alpha$-D-galactoside galactohydrolase, EC 3.2.1.22) are a group of exotype carbohydrases which catalyze the cleavage of terminal $\alpha-1,6$-linked galactosyl residues from a wide range of substrates, including linear and branched oligosaccharides, polysaccharides and synthetic substrates such as $\rho$ nitrophenyl- $\alpha$-D-galactopyranoside (Dey and Pridman, 1972). $\alpha$-Galactosidases have a number of biotechnological applications: in beet sugar industry, these enzymes are used to remove raffinose from beet molasses and to increase the yield of sucrose (Shibuya et al., 1995); they are also used to improve the gelling properties of galactomannans to be used as food thickeners (Bulpin et al., 1990) and to degrade the raffinose family sugars (raffinose, stachyose and verbascose) in food and feed materials such as soya meal or soya milk (Guimarães et al., 2001).

The raffinose oligosaccharides (RO), specially raffinose and stachyose, are considered the major factors responsible for flatulence after ingestion of soybean or other legumes. The enzymic hydrolysis of the $\mathrm{RO}$, therefore, may be of biotechnological interest. The hydrolysis of the RO may be accomplished by the $\alpha$-galactosidase, invertase or both. The $\alpha$-galactosidase cleaves the $\alpha-1,6$ linkage, joining the galactosyl residue to sucrose, yielding galactose and sucrose, while the invertase hydrolyses the $\alpha-1,2$ linkage, producing melibiose

*Author for correspondence 
and fructose. $\alpha$-Galactosidases are produced either by microorganisms, plants or animals, often in multiple forms (Dey and Pridman, 1972). The fungus Aspergillus fumigatus is a good producer of several proteolytic enzymes (Moser et al., 1994). In our laboratory, this mold was found to utilize native keratin (Santos et al., 1996) and several sugars including galactose, raffinose and melibiose (de Rezende and Felix, 1997, 1999). Here, we report the isolation, purification and characterization of an $\alpha$-galactosidase produced by a strain A. fumigatus.

\section{MATERIALS AND METHODS}

\section{Organism growth and $\alpha$-galactosidase production} Aspergillus fumigatus was isolated from a hot water fountain in Brazil (Caldas Novas - GO) and was maintained on potato-dextrose-agar medium. In order to select the carbon source, spores $\left(10^{7} \cdot \mathrm{mL}^{-1}\right)$ were transferred to $25 \mathrm{~mL}$ of liquid medium consisting of g. $\mathrm{L}^{-1} \mathrm{KH}_{2} \mathrm{PO}_{4} 7.0, \mathrm{~K}_{2} \mathrm{HPO}_{4}$ $2.0, \quad \mathrm{MgSO}_{4} .7 \mathrm{H}_{2} \mathrm{O} \quad 0.1, \quad\left(\mathrm{NH}_{4}\right)_{2} \mathrm{SO}_{4} \quad 1.0$, yeast extract 0.6 , and $1 \%(\mathrm{w} / \mathrm{v})$ of galactose, or lactose, or melibiose, or raffinose. After incubation at 42 ${ }^{\circ} \mathrm{C}$ and $120 \mathrm{rpm}$ for $12,24,36$ and $48 \mathrm{~h}$, the culture supernatants were collected by filtration through filter paper. The enzyme sample used for the purification process was produced in $4.75 \mathrm{~L}$ of the medium containing the galactose. After growth for $36 \mathrm{~h}$ at $42{ }^{\circ} \mathrm{C}$, the culture was filtered and the supernatants containing $\alpha$-galactosidase activity were concentrated approximately 10-fold by freeze-drying.

\section{Enzyme assay}

$\alpha$-Galactosidase was assayed using $\rho$-nitrophenyl$\alpha$-D-galactopyranoside ( $\rho N P G a l)$ as substrate. The assay system contained $200 \mu \mathrm{L}$ of $100 \mathrm{mM}$ sodium acetate buffer $\mathrm{pH} 5.0,250 \mu \mathrm{L}$ of $2 \mathrm{mM} \rho \mathrm{NPGal}$ solution and $50 \mu \mathrm{L}$ of enzyme preparation. The reaction was carried out for $15 \mathrm{~min}$ at $50{ }^{\circ} \mathrm{C}$ and was stopped by the addition of $1 \mathrm{ml}$ of $0.5 \mathrm{M}$ sodium carbonate. The amount of $\rho$-nitrophenol $(\rho N P)$ released was determined at $410 \mathrm{~nm}$. A unit (U) of enzyme was defined as the amount of $\alpha$ galactosidase which liberates $1 \mu \mathrm{mol}$ of $\rho \mathrm{NP}$ per min under the given assay conditions.

The activities against raffinose and sucrose were assayed for $60 \mathrm{~min}$ at $50{ }^{\circ} \mathrm{C}$ using a reaction mixture containing $400 \mu \mathrm{L}$ of $100 \mathrm{mM}$ sodium acetate buffer, $\mathrm{pH} 5.0,350 \mu \mathrm{L}$ of enzyme extract and $250 \mu \mathrm{L}$ of $4 \%(\mathrm{w} / \mathrm{v})$ substrate solutions. The amount of the reducing sugar produced was determined by the dinitrosalicylate method (Miller, 1956). The activity against melibiose was assayed using the same reaction system and determining the glucose formed by the glucoseoxidase method (Bergmeyer and Bernt, 1974).

Except for the chromatographic experiment, the enzyme activity values presented are mean values of triplicate assays. Standard deviations values were always smaller than $10 \%$ of the mean value.

\section{$\alpha$-Galactosidase purification}

A portion of the concentrated crude enzyme was applied to a BioGel P-100 (Pharmacia) column (80 x $1.5 \mathrm{~cm}$ ), packed and equilibrated with $50 \mathrm{mM}$ sodium phosphate buffer, $\mathrm{pH}$ 7.0. The column was washed with the same buffer and the samples were collected at a flow rate of $18 \mathrm{~mL} \cdot \mathrm{h}^{-1}$ at $4{ }^{\circ} \mathrm{C}$. The active protein fractions were pooled, concentrated by ultrafiltration on an Amicon membrane (PM 10), and chromatographed on a Q-Sepharose column $(15 \times 1.5 \mathrm{~cm})$, equilibrated and eluted with $100 \mathrm{mM}$ sodium phosphate buffer $\mathrm{pH}$ 7.0, followed by a linear gradient formed with $210 \mathrm{~mL}$ of phosphate buffer and $210 \mathrm{~mL}$ of the same buffer containing $0.8 \mathrm{M} \mathrm{NaCl}$. Samples of $4 \mathrm{~mL}$ were collected at a flow rate of $45 \mathrm{~mL} \cdot \mathrm{h}^{-1}$. The active protein fractions were concentrated by ultrafiltration as above, and loaded on a CMSepharose $(15 \times 2.0 \mathrm{~cm})$, equilibrated and eluted with $100 \mathrm{mM}$ sodium acetate buffer $\mathrm{pH}$ 5.0, followed by a linear gradient formed with $80 \mathrm{~mL}$ of $100 \mathrm{mM}$ of acetate buffer and $80 \mathrm{~mL}$ of the same buffer containing $0.8 \mathrm{M} \mathrm{NaCl}$. The enzyme preparation was analyzed by SDS-PAGE $12 \%$ (Laemmli, 1970) and was stained with silver reagent (Blum et al.,1987). The protein was quantified by the Coomassie Brilliant Blue binding method (Bradford, 1976) using bovine serum albumin as standard.

\section{Enzyme characterization}

The influence of the $\mathrm{pH}$ and temperature on the $\alpha$ galactosidase activity was studied using the assay system described above, but different buffer solutions $(\mathrm{pH} 3.0-7.5)$ or different incubation temperatures $\left(30-70{ }^{\circ} \mathrm{C}\right)$. For determination of thermal stability, the enzyme fractions were preincubated with buffer solution at $50{ }^{\circ} \mathrm{C}$ for several 
time periods at the optimum $\mathrm{pH}$. The residual activity was determined using the standard assay. Kinetics experiments were performed at $50{ }^{\circ} \mathrm{C}$ and $\mathrm{pH}$ 5.0. The Michaelis-Menten constant $\left(\mathrm{K}_{\mathrm{M}}\right)$ and maximal reaction rates $\left(\mathrm{V}_{\max }\right)$ were calculated by Michaelis-Menten and Lineweaver-Burk plots, using the computer software Curve Expert version 1.3 for Windows.

\section{RESULTS AND DISCUSSION}

The fungus A. fumigatus grew efficiently on a medium containing galactose, melibiose, or raffinose as carbon sources. Lactose was a poor carbon source (Table 1). $\alpha$-Galactosidase activity in the culture supernatant varied with the carbon source and the growth time (Table 2).

Table 1 - Mycelial mass (mg/ dry wt) produced on the culture fluid by the Aspergillus fumigatus growth at $42{ }^{\circ} \mathrm{C}$ for several times.

\begin{tabular}{lcccc}
\hline Growth time (h) & \multicolumn{4}{c}{ Carbon source $(\mathbf{1} \%, \mathbf{w} / \mathbf{v})$} \\
\cline { 2 - 5 } & Galactose & Lactose & Melibiose & Raffinose \\
\hline & & & & \\
12 & 36.30 & 18.80 & 25.80 & 44.90 \\
24 & 69.50 & 23.10 & 62.70 & 65.50 \\
36 & 84.20 & 19.50 & 85.20 & 79.00 \\
48 & 96.70 & 14.30 & 72.50 & 67.40 \\
\hline
\end{tabular}

Table 2 - $\alpha$-Galactosidase activity in the culture medium, concentrated of Aspergillus fumigatus grown on several carbon sources at $42^{\circ} \mathrm{C}$. U.mL $\mathrm{mL}^{-1}=$ units per $\mathrm{ml}$ of culture, $\mathrm{U} \cdot \mathrm{mg}^{-1}=$ units per $\mathrm{mg}$ of protein.

\begin{tabular}{|c|c|c|c|c|c|c|c|c|}
\hline \multirow[t]{2}{*}{ Carbon source } & \multicolumn{8}{|c|}{ Growth time (h) } \\
\hline & 12 & 24 & 36 & 48 & & & & \\
\hline & U.mL $\mathrm{mL}^{-1}$ & $\mathrm{U}^{\mathrm{m} \mathrm{mg}^{-1}}$ & U.mL $\mathrm{mL}^{-1}$ & U.mg $^{-1}$ & U.mL $\mathrm{mL}^{-1}$ & $\mathrm{U}^{\mathrm{m} \mathrm{mg}^{-1}}$ & U.mL $\mathrm{mL}^{-1}$ & U.mg $^{-1}$ \\
\hline Galactose & 0.56 & 0.14 & 5.78 & 0.82 & 35.68 & 3.96 & 24.09 & 4.01 \\
\hline Lactose & 1.23 & 0.62 & 1.69 & 0.85 & 2.37 & 0.79 & 3.11 & 0.78 \\
\hline Melibiose & 3.54 & 0.71 & 7.76 & 0.86 & 24.83 & 1.13 & 29.15 & 1.94 \\
\hline Raffinose & 1.81 & 0.96 & 4.79 & 0.50 & 6.54 & 0.74 & 9.61 & 0.71 \\
\hline
\end{tabular}

$1 \mathrm{U}=1 \mu \mathrm{mol}$ of $\rho \mathrm{NP}$ produced per minute.

The highest activity (35.68 U.mL ${ }^{-1}$ ) was induced by galactose which was followed by melibiose. This was in agreement with the results previously reported for the production of $\alpha$-galactosidase by A. fumigatus (de Rezende and Felix, 1997, 1999), Trichoderma reesei (Zeilinger et al., 1993) and in Penicillium simplicissimum (Luonteri et al., 1998). Surprisingly, although the raffinose sustained substantial growth, this substrate was almost as poor inducer as lactose. This could be due to the presence of the invertases, which in combination with background $\alpha$-galactosidase, hydrolyse the raffinose, producing simple sugars. These sugars could then be used for the production of the micelial mass, but were unable for further inducing $\alpha$-galactosidase production.

The gel filtration chromatography of the culture fluid of the A. fumigatus grown for $36 \mathrm{~h}$ at $42^{\circ} \mathrm{C}$ in galactose resulted in a single $\alpha$-galactosidase activity peak (not shown). The rechromatography of this active fraction on an ion exchange QSepharose column also resulted in an $\alpha$ galactosidase activity peak, which was eluted with $\mathrm{NaCl}$, at a concentration of about $0.5 \mathrm{M}$ (not shown). Further chromatography of this fraction on a CM-Sepharose column resulted in two main protein peaks ( $\mathrm{C} 1$ and $\mathrm{C} 2$ ), showing both $\alpha$ galactosidase activities (Fig 1). While the $\mathrm{C} 1$ fraction was eluted in the column void volume, the $\mathrm{C} 2$ fraction was eluted with a $\mathrm{NaCl}$ concentration of about $0.5 \mathrm{M}$. As for the elution of the first peak of $\alpha$-galactosidase in the void volume of the column its unlikely that we overcharged the system as this also happened with smaller volumes of enzyme. It was more likely that it represented a distinct isoform of the enzyme. However, we did not determine the $\mathrm{pI}$ values for these potential isoforms. The purification results are summarized in Table 3. $\alpha$-Galactosidase secreted by A. fumigatus was purified 177 -fold with a recovery of $3.04 \%$. The 
SDS-PAGE analysis revealed that the Biogel fraction, the Q-Sepharose fraction and the CM-Sepharose C1 fraction all contained several protein forms, while the $\mathrm{CM}$-Sepharose $\mathrm{C} 2$ fraction contained a single protein with $M w$ of $54.7 \mathrm{kDa}$ (Fig 2).

It was previously reported that $\alpha$-galactosidases from A. niger, T. reesei, Mortierella vinacea and Thermotoga neapolitana 5068 had $M w$ of $45 \mathrm{kDa}$ (Adya and Elbein, 1977), $50 \mathrm{kDa}$ (Zeilinger et al., 1993), $53 \mathrm{kDa}$ (Shibuya et al., 1995) and $61 \mathrm{kDa}$ (Duffaud et al., 1997), respectively.

The purified $\alpha$-galactosidase could not hydrolyze sucrose and raffinose was a very poor substrate, but the enzyme was able to hydrolyze melibiose. However, the affinity of the enzyme for melibiose was much lower than its affinity for $\rho N P G a l$. It is known (Varbanetes et al., 2001) that most microbial $\alpha$-galactosidases hydrolyze the synthetic substrate $\rho N P G a l$ more efficiently than the natural $\alpha$-galactosides. Moreover, $\alpha$-galactosidase from Aspergillus niger was reported (Kaneko et al., 1991) to hydrolyze exclusively the synthetic substrate and failed to split off the terminal $\alpha-1,6-$ bound galactose in linear structures like the melibiose, raffinose and stachyose. Nevertheless, previous findings indicated that $\alpha$-galactosidases from $T$. reesei (Zeilinger et al., 1993) and Bifidobacterium breve (Xiao et al., 2000) were able to hydrolyze raffinose.

A substantial activity against $\rho N P G a l$ was determined for the A. fumigatus purified $\alpha$ galactosidase at the temperature range of $45-65{ }^{\circ} \mathrm{C}$ and at the $\mathrm{pH}$ range of 4.0-5.0 (Figs. $3 \mathrm{~A}$ and $\mathrm{B}$ ).

The maximal substrate hydrolysis was achieved at $55{ }^{\circ} \mathrm{C}$ and $\mathrm{pH}$ 4.5. These optimum $\mathrm{pH}$ and temperature values were close to those determined for hydrolysis of $\rho$ NPGal by $\alpha$-galactosidase from $P$. purpurogenum (Shibuya et al., 1995) by the fungal raffinose-hydrolysing enzymes (de Rezende and Felix, 1999) and by $\alpha$-galactosidase from germinating soybean seed (Guimarães et al., 2001). The enzyme was thermostable and retained about $80 \%$ of its original activity after preincubation for $90 \mathrm{~min}$ at $50{ }^{\circ} \mathrm{C}$ (Fig 4).

The $\mathrm{K}_{\mathrm{M}}$ and $\mathrm{V}_{\max }$ values calculated by the Lineweaver-Burk reciprocal plot for hydrolysis of $\mathrm{NPGal}$ were $0.38 \mathrm{mM}$ and $0.16 \mu \mathrm{mol} . \mathrm{min}^{-1}$, respectively (Fig 5).

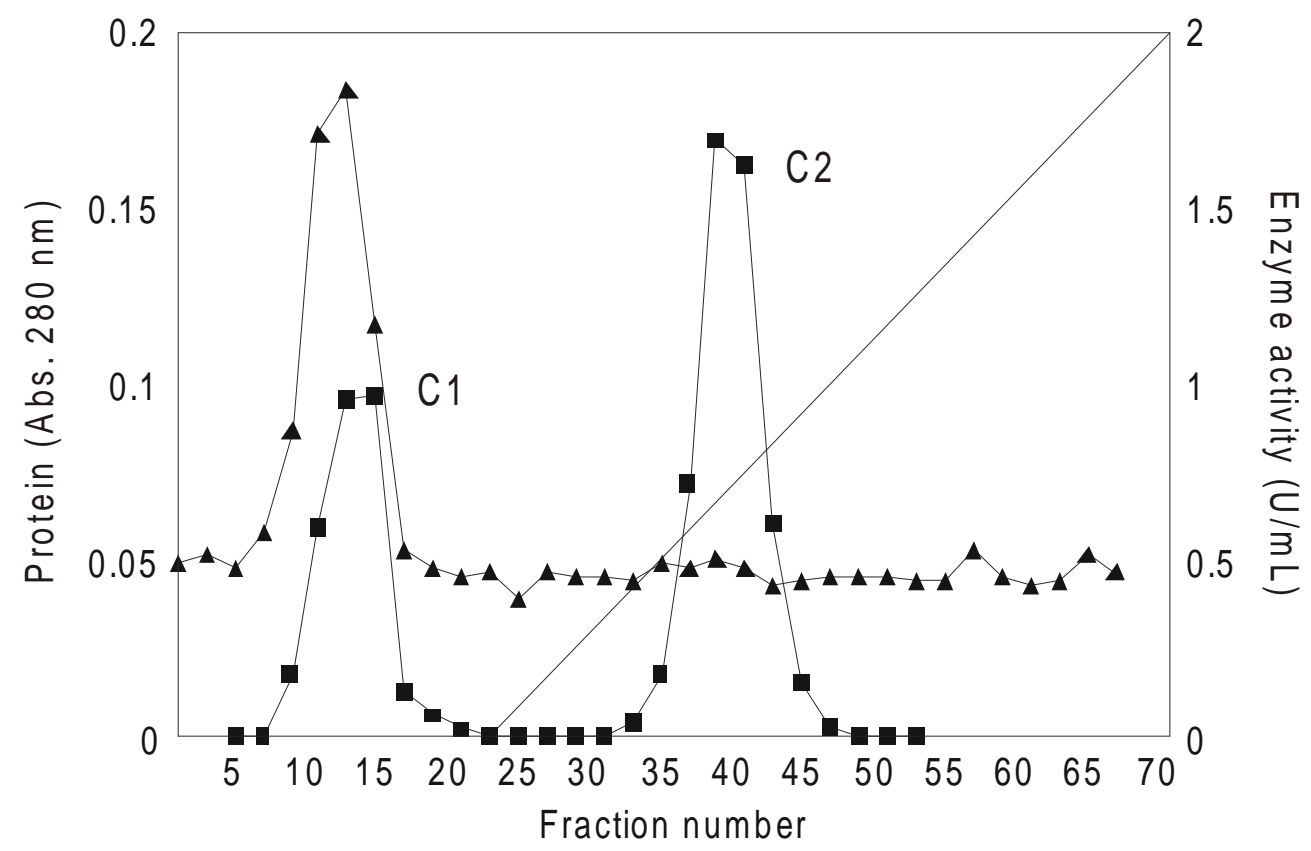

Figure 1 - Elution profile of the $\alpha$-galactosidase from Aspergillus fumigatus chromatographed on the CM-Sepharose column. Absorbance at $280 \mathrm{~nm}(\pi) ; \alpha$-galactosidase activity (匹); linear gradient of $\mathrm{NaCl}(0-0.8 \mathrm{M})(-)$ 
Table 3 - Summary of the purification steps of the $\alpha$-galactosidase from Aspergillus fumigatus.

\begin{tabular}{lccccc}
\hline \multicolumn{1}{c}{ Purification step } & $\begin{array}{c}\text { Total protein } \\
(\mathbf{m g})\end{array}$ & $\begin{array}{c}\text { Total activity } \\
(\mathbf{U})\end{array}$ & $\begin{array}{c}\text { Specific activity } \\
\left(\mathbf{U . m g}^{-1}\right)\end{array}$ & $\begin{array}{c}\text { Purification } \\
(\text { fold })\end{array}$ & $\begin{array}{c}\text { Recovery } \\
(\%)\end{array}$ \\
\hline Crude extract & 1230.50 & 69.94 & 0.05 & 1 & 100 \\
BioGel P100 & 16.66 & 54.20 & 3.25 & 65.0 & 77.49 \\
Q-Sepharose & 5.10 & 35.34 & 6.69 & 133.8 & 50.52 \\
CM-Sepharose (P2) & 0.24 & 2.13 & 8.85 & 177.0 & 3.04 \\
\hline
\end{tabular}

$\mathrm{U}_{\mathrm{mg}}{ }^{-1}=$ units of enzyme per $\mathrm{mg}$ of protein.

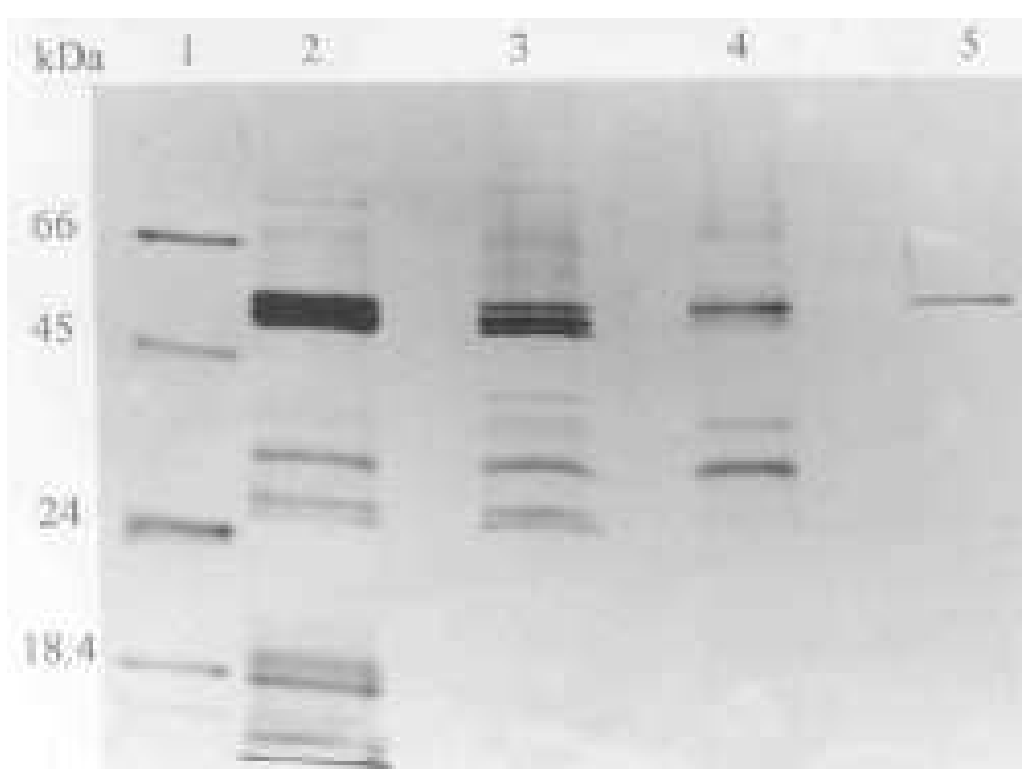

Figure 2 - SDS-PAGE (12\%) of Aspergillus fumigatus $\alpha$-galactosidase samples; 1 - molecular mass standards; 2- concentrated culture medium; 3- fraction P1 from the BioGel P100 column; 4- fraction Q1 from the Q-Sepharose column; 5- fraction C2 from the CM-Sepharose column

The $\mathrm{K}_{\mathrm{M}}$ value was close to that determined for the $\alpha$-galactosidases from coffee bean (Zhu et al., 1996) and from A. niger (Ademark et al., 2001), but lower than those reported for hydrolysis of $\rho N P G a l$ by $\alpha$-galactosidases from $T$ reesei (Zeilinger et al., 1993) and Penicillium sp. 23 (Varbanetes et al., 2001). Although the purified $\alpha$ galactosidase didnot hydrolyze raffinose and stachyose, the culture hydrolyzed the RO (de Rezende and Felix, 1997, 1999), indicating the ability of A. fumigatus to produce other $\alpha$ - galactosidase forms. These reported results indicated the potential of $A$. fumigatus for decreasing RO in soymilk. 

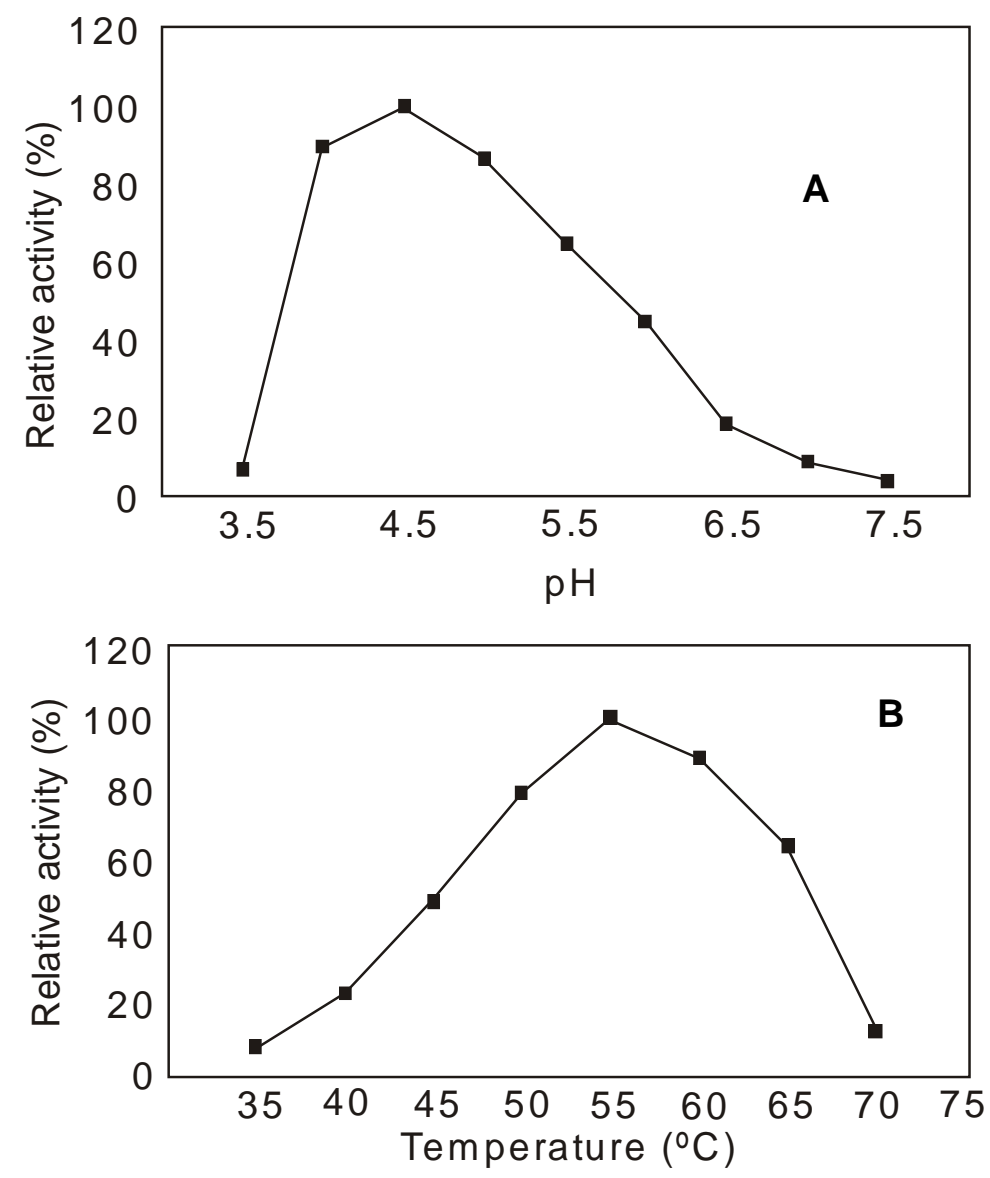

Figure 3 - Effects of $\mathrm{pH}(\mathrm{A})$ and temperature (B) on the activity of the Aspergillus fumigatus purified $\alpha$-galactosidase

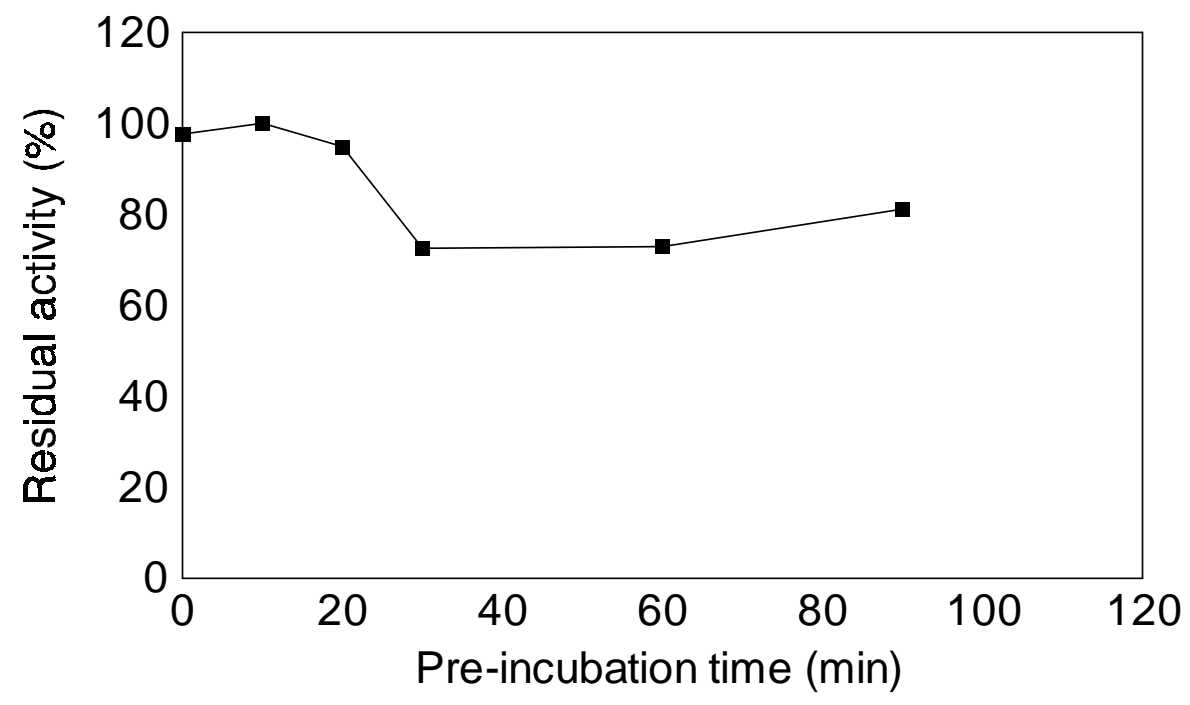

Figure 4 - Thermal stability of the Aspergillus fumigatus purified $\alpha$-galactosidase. The enzyme samples were pre-incubated for several times at $50{ }^{\circ} \mathrm{C}$, and then assayed as described in the text 


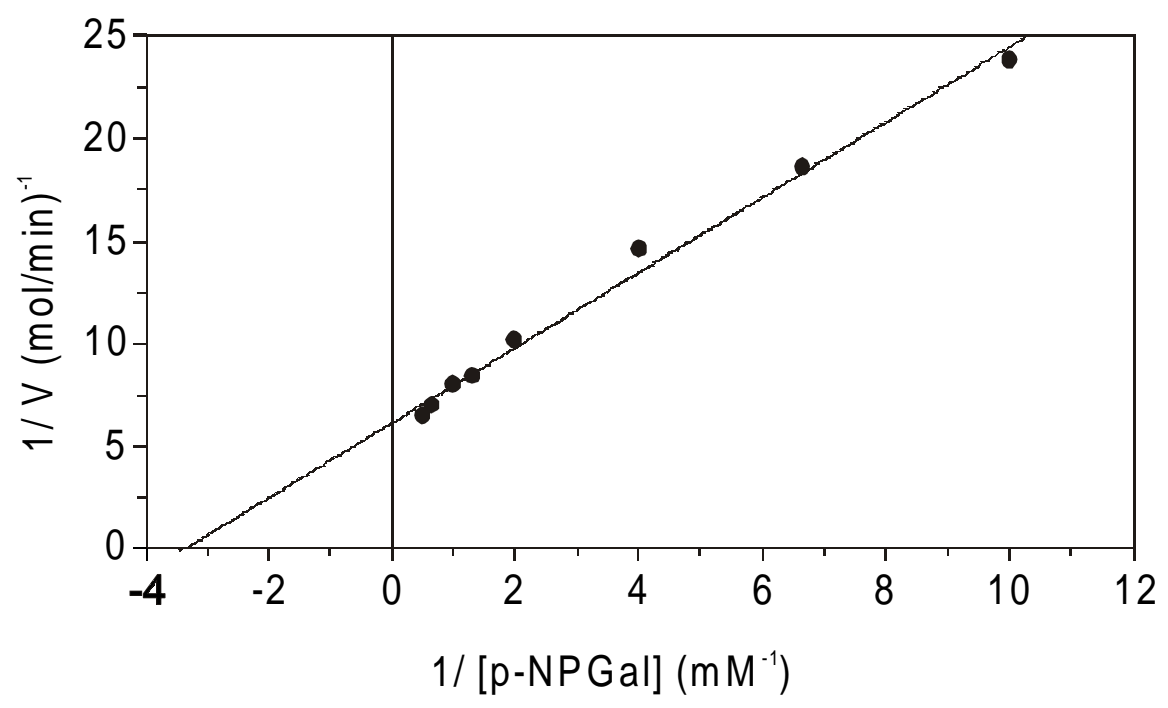

Figure 5 - Lineweaver-Burk plot for the Aspergillus fumigatus purified $\alpha$-galactosidase.

\section{ACKNOWLEDGEMENTS}

The authors thank FAPEMIG and FAPDF for financial support.

\section{RESUMO}

O fungo termofílico Aspergillus fumigatus secreta as enzimas invertase ( $\beta$-frutofuranosidase) e $\alpha$-galactosidase ( $\alpha$-D-galactosídeo galactohidrolase) que estão envolvidas na hidrólise completa dos oligossacarídeos de rafinose. A enzima $\alpha$-galactosidase foi produzida em meio de cultura do fungo Aspergillus fumigatus crescido por $36 \mathrm{~h}$ a $42{ }^{\circ} \mathrm{C}$ em meio mineral mínimo contendo os açúcares galactose, ou melibiose, ou rafinose como fontes de carbono. A enzima foi purificada por filtração em gel, seguida por duas cromatografias de troca iônica. A massa molecular da $\alpha$-galactosidase determinada por SDS-PAGE foi de $54,7 \mathrm{kDa}$. A atividade máxima da enzima purificada, utilizando o substrato $\rho$-nitrofenil- $\alpha$-Dgalactopiranosídeo ( $\rho$ NPGal) foi na faixa de $\mathrm{pH}$ entre 4,5 e 5,5 e a $55{ }^{\circ} \mathrm{C}$. A enzima manteve aproximadamente $80 \%$ de sua atividade original mesmo após pré-incubação por 90 minutos a 50 ${ }^{\circ} \mathrm{C}$. O valor de $\mathrm{K}_{\mathrm{M}}$ para o substrato $\rho N P G a l$ foi 0,3 mM. A enzima foi capaz de hidrolisar melibiose, mas sua atividade foi muito reduzida na presença do substrato rafinose.

\section{REFERENCES}

Ademark, P.; Larsson, M.; Tjerneld, F. and Stalbrand, H. (2001), Multiple $\alpha$-galactosidases from Aspergillus niger: purification, characterization and substrate specificities. Enzyme Microb. Technol., 29, 441-448.

Adya, S. and Elbein, A. D. (1977), Glycoprotein enzymes secreted by Aspergillus niger: purification and properties of $\alpha$-galactosidase. J. Bacteriol., 129, 850-856.

Bergmeyer, H. U. and Bernt, E. (1974), Determination of glucose with oxidase and peroxidase. In: Bergmeyer, H. U. (Eds.). Methods of Enzymatic Analysis. pp.1205-1215.

Blum, H., Beier, H. and Gross, H. (1987), Improved silver staining of plant proteins, RNA and DNA in polyacrylamide gels. Electrophoresis, 8, 93-99.

Bradford, M. M. (1976), A rapid and sensitive method for quantification of microgram quantities of protein utilizing the principle dye biding. Anal. Biochem., 72, 680-685.

Bulpin, P. V.; Gidley, M. J. and Jeffcoat, R. (1990), Development of a biotechnological process for the modification of galactomannan polymers with plant $\alpha$-galactosidase. Carbohydr. Polym., 12, 155-168.

Dey, P. M. and Pridham, J. B. (1972), Biochemistry of $\alpha$-galactosidases. Adv. Enzymol., 36, 91-130. 
Duffaud, G. D.; McCutchen, M. C.; Leduc, P.; Parker, K. N. and Kelly, R. M. (1997), Purification and characterization of extremely thermostable $\beta$-mannosidase, and $\alpha$-galactosidase from the hyperthermophilic Eubacterium Thermotoga neapolitana 5068. Appl. Environ. Microbiol., 63, 169-177.

Guimarães, V. M.; Rezende, S. T.; Moreira, M. A.; Barros, E. B. and Felix, C. R. (2001), Characterization of $\alpha$-galactosidases from germinating soybean seed and their use for hydrolysis of oligosaccharides. Phytochemistry, 58, 67-63.

Kaneko, R.; Kusakabe, I.; Ida, E. and Murakami, K. (1991), Substrate specificity of $\alpha$-galactosidase from Aspergillus niger 5-16. Agric. Biol. Chem., 55, 109-115.

Laemmli, U. K. (1970), Cleavage of structural proteins during the assembly of head of bacteriophage T4. Nature., 227, 680-683

Luonteri, E.;Alatalo, E.; Siika-aho, M.; Penttila, M. and Tenkanen, M. (1998), $\alpha$-Galactosidases of Penicillium simplicimum: production, purification and characterization of the gene encoding AGLI. Biotechnol. Appl Biochem., 28, 179-188.

Miller, G. L. (1956), Use of dinitrosalicylic acid reagent for determination of reducing sugar. Anal. Chem., 31, 426-428.

Moser, M.; Menz, G.; Blaser, K. and Crameri, R. (1994), Recombinant expression and antigenic properties of a 32-kilodalton extracellular alkaline protease, representing possible virulence factor form Aspergillus fumigatus. Infect. Immun., 62, 936-942.

Rezende, S. T. and Felix C. R. (1997), RaffinoseHydrolyzing activity of Aspergillus fumigatus. Biotechnol. Lett., 19, 217-220.

Rezende, S. T. and Felix C. R. (1999), Production and characterization of raffinose-hydrolynsing and invertase activities of Aspergillus fumigatus. Folia Microbiol., 44 : (2), 191-195.

Santos, R. M. B.; Firmino, A. A. P. and Felix, C. R. (1996), Keratinolytic activity of Aspergillus fumigatus Fresenius. Cur. Microbiol., 33, 364-370.

Shibuya, H.; Kobayashi, H.; Park, G. G.; Komatsu, Y.; Sato, T.; Kaneko, R.; Nagasaki, H.; Yoshida, S.; Kasamo, K. and Kusakabe, I. (1995), Purification and some properties of $\alpha$-galactosidases from Penicillium purpurogenum. Biosci. Biotech. Biochem., 59, 2333-2335.
Varbanetes, L. D.; Malanchuk, V. M.; Buglova, T. T. and Kuhlmann, R. A. (2001), Penicillium sp. 23 $\alpha$-galactosidase: purification and substrate specificity. Carbohydr. Polym., 44,357-363.

Xiao, M.; Tanaka, K.; Qian, X. M.; Yamamoto, K. and Kumagai, H. (2000), High-yield production and characterization of $\alpha$-galactosidase from Bifidobacterium breve grown on raffinose. Biotechnol. Lett., 22 : (9), 747-751.

Zeilinger, S.; Kristufek, D.; Arissan-Atac, I.; Hodits, R. and Kubicek, C. P. (1993), Condition of formation, purification, and characterization of an $\alpha$ galactosidase of Trichodrema reesei RUT C-30. Appl. Environ. Microbiol., 59, 1347-1353.

Zhu, A.; Leng, L.; Monahan, C.; Zhang, Z.; Hurst, R.; Lenny, L. and Goldstein, J. (1996), Characterization of recombinant $\alpha$-galactosidase for use in seroconversion from blood group $\mathrm{B}$ to $\mathrm{O}$ of human erythrocytes. Arch. Biochem. Biophys., 327, 324-329.

Received: July 14, 2003; Revised: April 20, 2004; Accepted: September 17, 2004. 